\title{
The coracoscapular joint of neornithine birds-extensive homoplasy in a widely neglected articular surface of the avian pectoral girdle and its possible functional correlates
}

\author{
Gerald Mayr ${ }^{1}$ (i)
}

Received: 4 January 2021 / Revised: 16 February 2021 / Accepted: 24 February 2021 / Published online: 27 May 2021

(c) The Author(s), corrected publication 20212021

\begin{abstract}
A survey is given of the morphological variation of the coracoscapular joint of neornithine birds. In Mesozoic stem group representatives, the coracoid exhibits a deeply concave cotyla scapularis, which articulates with a globose tuberculum coracoideum of the scapula. This morphology is likely to be functionally related to the development of a powerful supracoracoideus muscle and the formation of a triosseal canal as a pulley for the tendon of this muscle. In neornithine birds, the coracoid articulates with the scapula either via a concave cotyla or a flat facies articularis, with the latter largely restricting movements of the coracoid to the paramedian plane. Ancestral state reconstruction suggests that a cotyla scapularis is plesiomorphic for Neornithes and that a flat facies articularis scapularis evolved at least 13 times independently within the clade. For several lineages, the transition to a flat facies articularis scapularis can be traced in the fossil record, and the replacement of a cupshaped cotyla by a flat articular facet seems to have been due to various functional demands. Often, a flat facies articularis scapularis is associated with reduced shafts of the furcula. A weakly developed furcula enables transverse movements of the coracoid and therefore enables a restriction of the mobility of the coracoscapular joint to the paramedian plane. In taxa with a large crop, a flat facies articularis scapularis is likely to be associated with a reorganization of the pectoral musculature, whereas in procellariiform birds, the transition from a cotyla to a facies articularis appears to have been correlated with the capacity for sustained soaring without wing flapping.
\end{abstract}

Keywords Aves · Coracoid · Evolution · Functional morphology $\cdot$ Locomotion

\section{Introduction}

In non-avian theropods, coracoid and scapula are either coossified into a scapulocoracoid or articulate via a straight suture (e.g., Jasinoski et al. 2006; Senter 2006). This plesiomorphic condition also occurs in early diverging taxa of the avian stem lineage (Wang et al. 2018).

Well-defined and more localized articular facets characterize Ornithothoraces, the clade including the Cretaceous Enantiornithes and the Ornithuromorpha. These latter two taxa distinctly differ in the morphology of the coracoscapular joint, with the coracoid of the Enantiornithes having a

Gerald Mayr

Gerald.Mayr@senckenberg.de

1 Ornithological Section, Senckenberg Research Institute and Natural History Museum Frankfurt, Senckenberganlage 25, 60325 Frankfurt am Main, Germany convex articular facies for the scapula (Chiappe and Walker 2002), whereas the coracoid of early representatives of the Ornithuromorpha- the taxon comprising the avian crown group (Neornithes) - is characterized by a deeply concave cotyla scapularis, which articulates with a globose tuberculum coracoideum of the scapula.

The formation of a deeply concave, cup-shaped cotyla scapularis is likely to have been functionally correlated with the evolution of a modern-type triosseal canal. This canal forms a pulley for the tendon of musculus supracoracoideus, which elevates the wing, and is one of the derived characteristic of the Ornithuromorpha (Fig. 1a-c; Mayr 2017b). Mesozoic species of the Ornithuromorpha were predominantly terrestrial birds, which therefore had to initiate their takeoffs from the ground, and-as indicated by the development of a large sternal keel and a functional triosseal canal-musculus supracoracoideus underwent a strong development in these birds (Mayr 2017b). Their cup-like coracoscapular joint enabled multidirectional mobility of the coracoid relative to the 


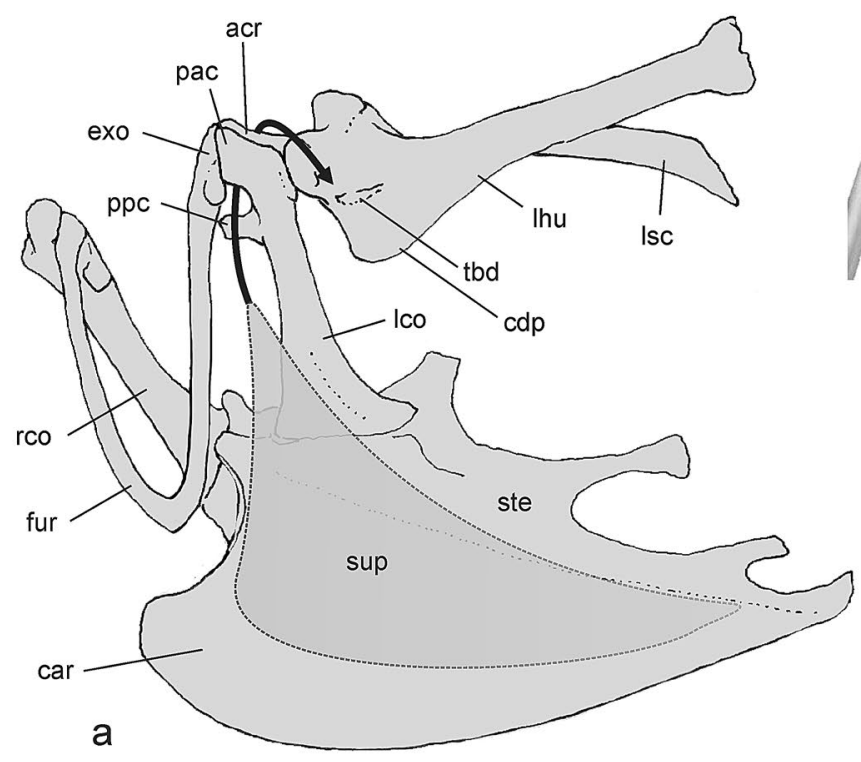

Fig. 1 a Wing and pectoral girdle bones of a pigeon (Columba sp.), with the dotted area indicating the surfaces of the coracoid and sternum occupied by musculus supracoracoideus (after George and Berger 1966: Fig. III.1). b, c Coracoscapular joint of $\mathbf{b}$ the Common Woodpigeon, Columba palumbus (Columbidae; left side, craniolateral view), and $\mathbf{c}$ the Ring-necked Pheasant, Phasianus colchicus (Phasianidae; right side, caudodorsal view). d-f Omal extremity of the left coracoid (dorsal view) of $\mathbf{d}$ the Early Cretaceous Yixianornis grabaui with a deeply cup-shaped cotyla scapularis (IVPP V 1363; right coracoid, mirrored; surrounding matrix digitally removed), e Sagittarius serpentarius (Accipitriformes, Sagittariidae) with a deeply cup-shaped cotyla scapularis, and f Rhynchotus rufescens (Tinamiformes, Tinamidae) with a flat facies articularis scapularis.

scapula and may have been critical to absorb mechanical strain on the pectoral girdle elements resulting from contractions of a powerful supracoracoideus muscle.

All volant and some flightless Mesozoic birds of which the coracoid is known have a cup-shaped cotyla scapularis (Fig. 1d; Clarke 2004; Clarke et al. 2006; Longrich 2009; Wang et al. 2015, 2016; Bell and Chiappe 2020), which is likely to be plesiomorphic for Neornithes. However, the coracoscapular joint of extant birds shows much variation, and a cup-shaped cotyla scapularis is replaced by a flat articular facet in many taxa (Fig. 1f).

In birds with a deep, cup-shaped cotyla scapularis, the articulation between the coracoid and scapula resembles a ball-and-socket joint, but a true synovial joint is not formed (Fürbringer 1888). Moreover, the mobility of the coracoscapular joint is constrained by the ligamentum coracoscapulare interosseum, which is formed by elastic
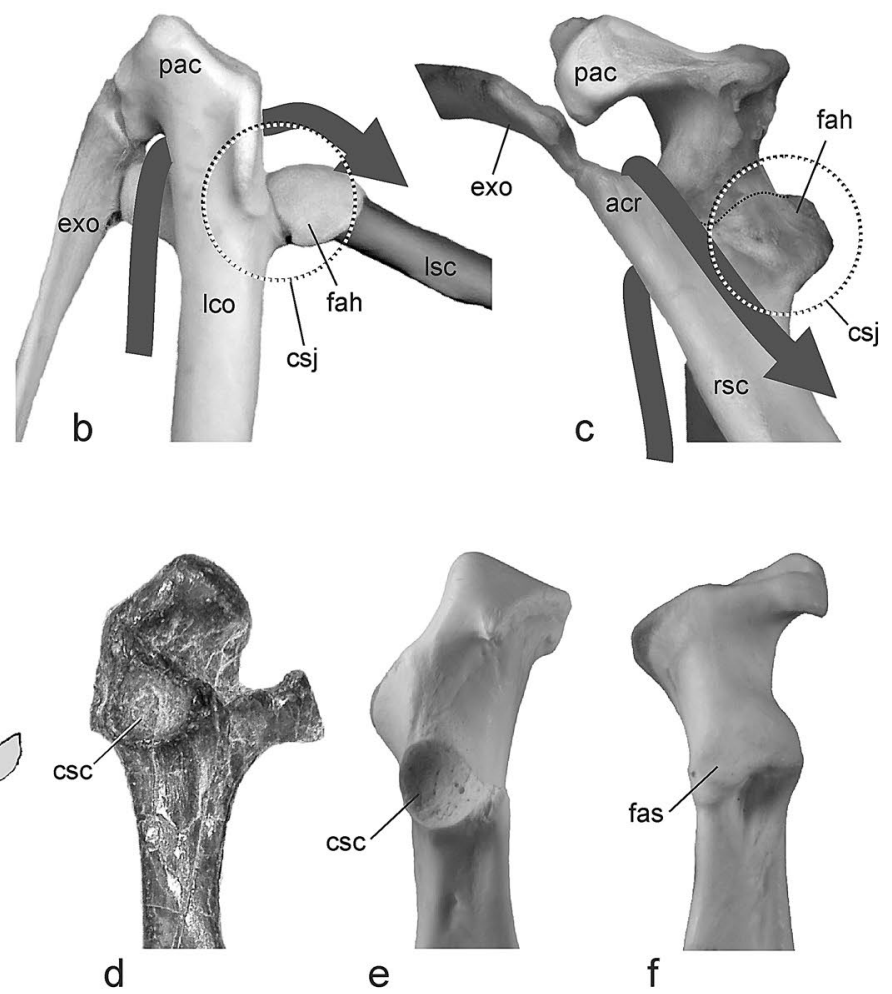

The arrows in $\mathbf{a}-\mathbf{c}$ indicate the course of the tendon of the supracoracoideus muscle, which passes through the triosseal canal formed by the processus acrocoracoideus of the coracoid, the extremitas omalis of the furcula, and the acromion of the scapula. acr acromion of scapula, car carina sterni, $c d p$ crista deltopectoralis of humerus, $c s c$ cotyla scapularis, csj coracoscapular joint, exo extremitas omalis of furcula, fah facies articularis humeralis of scapula, fas facies articularis scapularis, fur furcula, lco left coracoid, lhu left humerus, $l s c$ left scapula, pac processus acrocoracoideus of coracoid, $p p c$ processus procoracoideus of coracoid, rco right coracoid, ste sternum, sup musculus supracoracoideus, $t b d$ tuberculum dorsale of humerus. Not to scale

cartilage and fully envelops the coracoscapular joint, thereby firmly connecting the coracoid to the scapula (Baumel and Raikow 1993: 161). This ligament also forms the glenoid cavity for the articulation with the humerus. A cup-shaped cotyla scapularis in general facilitates a multidirectional mobility of the coracoid and scapula relative to each other, but the ligamental connection of the two bones does not enable true rotational movements.

Although Fürbringer (1888) already addressed the morphology of the coracoscapular joint of extant birds in some detail, no comprehensive survey of the morphological variation has been published, nor has the comparative morphology of the joint been considered in otherwise detailed accounts of the functional morphology of the avian wing and pectoral girdle (see, e.g., Sy 1936; Stegmann 1964).

However, the paleornithological literature includes descriptions of a fair number of fossil taxa that document 
a transition from a cup-like cotyla scapularis to a flat facies articularis scapularis. In the present study, these data are for the first time compiled and the variation of the coracoscapular articulation of extant birds is examined across a comprehensive taxonomic sampling. Although the main objective of this study was to gather the available morphological data, some possible functional correlates of the observed variation in the coracoscapular joint of fossil and extant neornithine birds are also discussed. An in-depth functional interpretation will, however, have to await future studies of the soft tissue anatomy, which was beyond the scope of the present analysis.

\section{Material and methods}

Institutional abbreviations: CM-Canterbury Museum, Christchurch, New Zealand; GMH-Geiseltalsammlung, Martin-Luther Universität of Halle-Wittenberg, Germany; IRSNB-Institut royal des Sciences naturelles de Belgique, Belgium; IVPP-Institute of Vertebrate Paleontology and Paleoanthropology, Beijing, China; LACM-Los Angeles County Museum, Los Angeles, California, USA; MNHN_Museo Nacional de Historia Natural, Santiago, Chile; SMF-Senckenberg Research Institute Frankfurt, Frankfurt Germany; UCBL-Université Claude Bernard, Lyon, France; UMMP-University of Michigan, Museum of Paleontology, Ann Arbor, Michigan, USA; WDC-The Wyoming Dinosaur Center, Thermopolis, Wyoming, USA.

The nomenclature of the extant species follows the IOC World Bird List (https://www.worldbirdnames.org). To describe the direction of movements relative to the body axes, the term paramedian and transverse are used, with the former describing movements in the dorsoventral plane (parasagittal in human anatomy), whereas the latter pertains to mediolateral movements in a plane at a right angle to the rostrocaudal body axis. Skeletons of extant birds were examined in the ornithological collection of Senckenberg Research Institute Frankfurt.

Ancestral character states were reconstructed under the parsimony criterion with Mesquite 2.71 (Maddison and Maddison 2009) based on a recent tree topology resulting from analysis of transcriptome data (Kuhl et al. 2021).

\section{Results}

The coracoid and scapula are co-ossified and form a scapulocoracoid in all flightless palaeognathous birds. The different morphologies of the coracoscapular joint of volant Neornithes are summarized in Table 1.

A deeply concave, cup-shaped cotyla scapularis with a circular outline is found in the anseriform Anhimidae and
Anseranatidae, in the Opisthocomidae, Otididae, Ciconiidae, in the pelecaniform Pelecanidae and Balaenicipitidae, and in the accipitriform Sagittariidae. It also occurs in gruiform birds (Gruidae, Aramidae, Psophiidae, Rallidae, and Heliornithidae), in all Charadriiformes, in the Pterocliformes, and in the Ardeidae. A cotyla scapularis is also present though less deeply concave in the Eurypygidae, Rhynochetidae, Scopidae, Oceanitidae, Threskiornithidae, Accipitridae, and some representatives of the Strisores (Nyctibiidae, Steatornithidae, and apodiform birds).

A flat facies articularis scapularis is present in the palaeognathous Tinamidae, and in the Galliformes, Suliformes, Sphenisciformes, all Procellariiformes except the Oceanitidae, Phaethontiformes, Columbiformes, Cuculiformes, Mesitornithiformes, Musophagiformes, Caprimulgidae, Podargidae, Aegothelidae, Cathartidae, Falconidae, Psittaciformes, Passeriformes, Coliiformes, Strigiformes, as well as all members of Eucavitaves (the clade including Trogoniformes, Coraciiformes, and Piciformes; Yuri et al. 2013). Of at least seven of these latter taxa, stem group representatives are known, which have a deep cotyla scapularis:

(1) Galliformes: a cup-like cotyla scapularis occurs in all early Paleogene stem group Galliformes, that is, the Gallinuloididae (Fig. 2a; Mayr and Weidig 2004; Mayr 2006), Quercymegapodiidae (Mourer-Chauviré 1992a, 2000), and Paraortygidae (Mourer-Chauviré 1992a; MourerChauviré et al. 2017; Mayr and Smith 2013). The exact interrelationships between the Paraortygidae, Quercymegapodiidae, and crown Galliformes are uncertain, but the Gallinuloididae are the earliest diverging clade and a cup-like cotyla scapularis is clearly plesiomorphic for Galliformes as a total group (Mayr 2017a).

(2) Procellariiformes: coracoids are known from only a few Paleogene Procellariiformes, but the coracoid of the early Oligocene Diomedeoididae has a cup-shaped cotyla scapularis (Fig. 2f; De Pietri et al. 2009; Mayr and Smith 2012). The exact affinities of the Diomedeoididae are unresolved and these birds resulted as the sister taxon of either all crown group Procellariiformes or of the Diomedeidae (Mayr and Smith 2012). Among extant Procellariiformes, the Diomedeidae, Hydrobatidae, and Procellariidae have a flat facies articularis scapularis, whereas there is a cotyla scapularis of varying depth in the Oceanitidae. Current phylogenetic reconstructions suggest a sister group relationship between the Diomedeidae and all other crown group Procellariiformes (Kuhl et al. 2021), so that a flat facies articularis scapularis evolved at least two times independently within Procellariiformes, in the Diomedeidae and in the clade formed by Hydrobatidae and Procellariidae. A cup-shaped cotyla scapularis is also present in a procellariiform coracoid from the late Eocene of Antarctica, which was referred to the Gaviiformes by 
Hospitaleche and Gelfo (2015). As noted by Mayr and Goedert (2017), this coracoid is from a procellariiform bird and may belong to the stem group albatross Notoleptos, which was found in coeval strata (Hospitaleche and Gelfo 2017).

(3) Sphenisciformes: all early Paleogene stem group Sphenisciformes of which the coracoid is known exhibit a deeply excavated cotyla scapularis, which is particularly well-developed in the Paleocene taxa Кироирои, Muriwaimanu, Sequiwaimanu, and Kumimanu (Fig. 2h; Blokland et al. 2019; Mayr and Goedert 2017; Mayr et al. 2018). A somewhat shallower cotyla is also present in the late Eocene taxa Anthropornis and Palaeeudyptes (Jadwiszczak 2006; Hospitaleche 2016) and in the late Oligo- cene Kairuku (Ksepka et al. 2012). In crown group Sphenisciformes, the cotyla scapularis is only weakly concave or there is a flat facies articularis scapularis (Fig. 2i).

(4) Suliformes: a slightly concave articular facet is present in the early Eocene stem group frigatebird Limnofregata (Olson 1977) and in the late Oligocene Borvocarbo, which is considered to be a stem group representative of the Phalacrocoracidae (MourerChauviré et al. 2004). A deeply concave cotyla scapularis characterizes the coracoid of many Plotopteridae, which are extinct wing-propelled diving seabirds from the North Pacific and are hypothesized to be part of the Suliformes (Fig. 2j, k; Mayr 2017a; Mayr et al. 2021a).
Table 1 Overview of different configurations of the coracoscapular joint of extant neornithine taxa and possibly correlated traits involving the morphology of the pectoral girdle and wing bones, as well as major ontogenetic categories. Taxa with a flat facies articularis scapularis are highlighted in gray. CSJ morphology of the coracoscapular joint (0: cotyla scapularis; 1: facies articularis scapularis), EXS furcula, width of extremitas sternalis (0: similar to furcular scapus or wider; 1: narrow or completely reduced), EXO furcula, extremitas omalis with articular facet for coracoid ( $0:$ no; 1: yes), FNS coracoid, foramen nervi supracoracoidei ( 0 : present; 1 : absent), TBD humerus, tuberculum dorsale strongly developed ( 0 : no; 1 : yes), HUL humerus length relative to coracoid ( 0 : humerus twice as long as coracoid or shorter than twofold length of coracoid; 1 : humerus more than twice as long as coracoid), ONT ontogeny (0: precocial, 1: altricial; after Temrin and Tullberg 1995)

\begin{tabular}{|c|c|c|c|c|c|c|c|}
\hline & CSJ & EXS & EXO & FNS & TBD & HUL & ONT \\
\hline Tinamiformes & 1 & 0 & 0 & 1 & 1 & 0 & 0 \\
\hline Galliformes & 1 & 0 & 0 & 1 & 1 & 0 & 0 \\
\hline Anseriformes: Anhimidae & 0 & 0 & 0 & 0 & 0 & 1 & 0 \\
\hline Anseriformes: Anseranatidae & 0 & 0 & 0 & 0 & 0 & 1 & 0 \\
\hline Anseriformes: Anatidae & 0 & 0 & 0 & 01 & 1 & 01 & 0 \\
\hline Phoenicopteriformes & 0 & 0 & 0 & 0 & 0 & 1 & 0 \\
\hline Podicipediformes & 1 & 1 & 0 & 1 & 0 & 1 & 0 \\
\hline Opisthocomiformes & 0 & 0 & 1 & 1 & 0 & 0 & 0 \\
\hline Gaviiformes & 0 & 1 & 0 & 0 & 0 & 1 & 0 \\
\hline Sphenisciformes & 1 & 1 & 0 & 1 & 1 & 0 & 1 \\
\hline Procellariiformes & 01 & 0 & 0 & 0 & 0 & 1 & 1 \\
\hline Ciconiidae & 0 & 0 & 0 & 01 & 01 & 1 & 1 \\
\hline Suliformes & 1 & 01 & 1 & 1 & 01 & 1 & 1 \\
\hline Ardeidae & 0 & 0 & 0 & 1 & 1 & 1 & 1 \\
\hline Threskiornithidae & 0 & 0 & 0 & 1 & 0 & 1 & 1 \\
\hline Pelecanidae & 0 & 0 & 1 & 0 & 0 & 1 & 1 \\
\hline Scopidae & 0 & 0 & 1 & 1 & 0 & 1 & 1 \\
\hline Balaenicipitidae & 0 & 0 & 1 & 0 & 0 & 1 & 1 \\
\hline Phaethontiformes & 1 & 0 & 0 & 0 & 0 & 0 & 1 \\
\hline Eurypygiformes: Eurypygidae & 0 & 0 & 0 & 1 & 0 & 0 & 0 \\
\hline Eurypygiformes: Rhynochetidae & 0 & 0 & 0 & 1 & 1 & 1 & 0 \\
\hline Otidiformes & 0 & 0 & 0 & 01 & 0 & 1 & 0 \\
\hline Gruiformes: Gruidae & 0 & 0 & 0 & 0 & 0 & 1 & 0 \\
\hline Gruiformes: Aramidae & 0 & 0 & 0 & 0 & 0 & 1 & 0 \\
\hline Gruiformes: Psophiidae & 0 & 0 & 0 & 0 & 0 & 0 & 0 \\
\hline
\end{tabular}


Table 1 (continued)

\begin{tabular}{|c|c|c|c|c|c|c|c|}
\hline Gruiformes: Rallidae & 0 & 1 & 0 & 0 & 0 & 0 & 0 \\
\hline Gruiformes: Heliornithidae & 0 & 0 & 0 & 0 & 0 & 0 & 1 \\
\hline Charadriiformes: Charadrii & 0 & 0 & 0 & 0 & 1 & 0 & 0 \\
\hline Charadriiformes: Scolopaci & 0 & 0 & 1 & 1 & 1 & 0 & 0 \\
\hline Charadriiformes: Lari & 0 & 0 & 1 & 0 & 1 & 1 & 0 \\
\hline Charadriiformes: Turnicidae & 0 & 0 & 0 & 1 & 1 & 0 & 0 \\
\hline Cuculiformes & 1 & 0 & 0 & 1 & 0 & 0 & 1 \\
\hline Musophagiformes & 1 & 1 & 1 & 0 & 0 & 0 & 1 \\
\hline Columbiformes & 1 & 1 & 0 & 1 & 1 & 0 & 1 \\
\hline Pterocliformes & 0 & 1 & 0 & 1 & 1 & 0 & 0 \\
\hline Mesitornithiformes & 1 & 1 & 0 & 1 & 1 & 0 & 0 \\
\hline Strisores: Caprimulgidae & 1 & 0 & 1 & 1 & 1 & 0 & 0 \\
\hline Strisores: Steatornithidae & 0 & 0 & 0 & 1 & 0 & 0 & 1 \\
\hline Strisores: Nyctibiidae & 0 & 0 & 1 & 1 & 0 & 1 & 1 \\
\hline Strisores: Podargidae & 1 & 1 & 0 & 1 & 0 & 1 & 1 \\
\hline Strisores: Aegothelidae & 1 & 0 & 0 & 0 & 0 & 0 & 1 \\
\hline Strisores: Apodidae & 0 & 0 & 1 & 0 & 1 & 0 & 1 \\
\hline Strisores: Hemiprocnidae & 0 & 0 & 1 & 0 & 1 & 0 & 1 \\
\hline Strisores: Trochilidae & 0 & 0 & 1 & 0 & 0 & 0 & 1 \\
\hline Cariamiformes & 0 & 1 & 1 & 1 & 0 & 1 & 1 \\
\hline Accipitriformes: Cathartidae & 1 & 0 & 1 & 0 & 0 & 1 & 1 \\
\hline Accipitriformes: Sagittariidae & 0 & 0 & 0 & 0 & 0 & 1 & 1 \\
\hline Accipitriformes: Accipitridae & 0 & 0 & 1 & 01 & 0 & 1 & 1 \\
\hline Falconiformes & 1 & 0 & 1 & 01 & 0 & 0 & 1 \\
\hline Psittaciformes & 1 & 1 & 0 & 1 & 1 & 0 & 1 \\
\hline Strigiformes & 1 & 1 & 0 & 0 & 0 & 1 & 1 \\
\hline Coliiformes & 1 & 0 & 0 & 1 & 0 & 0 & 1 \\
\hline Leptosomiformes & 1 & 1 & 1 & 0 & 0 & 1 & 1 \\
\hline Bucerotiformes & 1 & 1 & 0 & 1 & 0 & 0 & 1 \\
\hline Upupiformes & 1 & 0 & 0 & 1 & 0 & 0 & 1 \\
\hline Trogoniformes & 1 & 1 & 0 & 1 & 1 & 0 & 1 \\
\hline Coraciiformes & 1 & 1 & 0 & 1 & 0 & 0 & 1 \\
\hline Meropidae & 1 & 1 & 0 & 1 & 0 & 0 & 1 \\
\hline Alcedinidae & 1 & 1 & 0 & 1 & 0 & 0 & 1 \\
\hline Momotidae & 1 & 1 & 0 & 1 & 0 & 0 & 1 \\
\hline Piciformes & 1 & 1 & 0 & 1 & 0 & 0 & 1 \\
\hline Passeriformes & 1 & 1 & 0 & 1 & 0 & 0 & 1 \\
\hline
\end{tabular}

(5) Psittaciformes: a concave cotyla scapularis is present in the middle Eocene Namapsittidae (MourerChauviré et al. 2017) and in the late Eocene Quercypsittidae (Fig. 21; Mourer-Chauviré 1992b), both of which are considered to be stem group representatives of the Psittaciformes.

(6) Coliiformes: a moderately concave cotyla scapularis is also found in the Eocene Sandcoleidae, which are 
stem group representatives of the Coliiformes (Fig. 2n; Houde and Olson 1992; Mayr 2017a).

(7) Strigiformes: the coracoid of most early Paleogene stem group Strigiformes is unknown. However, a cotyla scapularis is present in the early Eocene Primoptynx (Fig. 2p; Mayr et al. 2020).

Ancestral state reconstruction based on the morphology of the extant species did not allow a conclusive reconstruction of the ancestral state for many taxa (Fig. 3a). However, an analysis, in which Galliformes, Sphenisciformes, Procellariiformes, Suliformes, Strigiformes, Coliiformes, and Psittaciformes were scored as having a cotyla scapularis (the presumed ancestral state for these clades), shows that a cotyla scapularis is plesiomorphic for neornithine birds (Fig. 3b). If reversals into the plesiomorphic state are allowed for, a flat facies articularis scapularis evolved at least 13 times independently, in the stem lineages of the (1) Tinamidae, (2) Galliformes, (3) Podicipediformes, and (4) the clade including Columbiformes, Cuculiformes, Mesitornithiformes, Musophagiformes, Caprimulgidae, Podargidae, and Aegothelidae, as well as in the stem lineages of the (5) Suliformes, (6) Phaethontiformes, (7) Sphenisciformes, (8) Procellariiformes, (9) the clade (Falconidae + Psittaciformes + Passeriformes), the (10) Cathartidae, (11) Coliiformes, (12) Strigiformes, and the (13) Eucavitaves (Fig. 3b). Here, it is considered more likely that the evolutionary transformations of the coracoscapular articulation were unidirectional, from a cup-like cotyla scapularis to a flat facies articularis scapularis. This assumption would raise the number of an independent origin of a flat facies articularis scapularis to 20 and is supported by the fact that flattening of the cotyla scapularis is a recurrent theme in the evolution of many only distantly related lineages, whereas no example of the reverse transition (from a flat facies to a deep cotyla) exists.

\section{Discussion}

As detailed in the introduction, a cup-like coracoscapular joint is an apomorphy of the Ornithuromorpha and enables multidirectional mobility of the coracoid relative to the scapula, which in birds is fixed in a relatively immobile position to the ribcage. A shallow facies articularis scapularis, by contrast, restricts motion mainly to a paramedian plane, which raises the question, why a cup-shaped cotyla was replaced by a flat articular facet in many different lineages of neornithine birds.

The fact that stem group representatives of various extant taxa with a flat facies articularis scapularis have a concave cotyla scapularis is indicative of a rapid diversification of neornithine birds at a time, where the stem species of most major clades still had a plesiomorphic, cup-shaped cotyla scapularis. Ontogenetically, a cup-like cotyla scapularis develops from a flat articulation surface (Fig. 4c, d), so that a flat facies articularis may be a paedomorphic trait. Indeed, most birds with a flat facies are altricial (Table 1), and a delay in skeletal maturation may have favored retention of a flat facies in adulthood. Still, there are notable exceptions, with precocial taxa with a flat facies articularis scapularis including Tinamiformes, crown group Galliformes, Podicipediformes, and Mesitornithiformes, whereas the Pelecanidae, Ciconiidae, Apodiformes and Cariamiformes are altricial and have a cup-like cotyla.

The transition from a cup-like cotyla scapularis to a flat facies articularis scapularis does not involve major changes in other aspects of coracoid morphology (Fig. 2), but many taxa with a deeply concave cotyla scapularis, such as the Anhimidae and Pelecanidae, have an unusually robust, U-shaped furcula. In taxa with a flat facies articularis scapularis, by contrast, the furcula often has very narrow shafts, especially at its sternal extremity (Table 1; Fig. 4). In Mesozoic Ornithuromorpha with a deeply concave cotyla scapularis, the furcula was also much more robust than it is in most extant birds and formed a rigid unit that appears to have been resistant to transversal bending.

To some degree, the shape of the furcula of birds correlates with flight style (Hui 2002; Close and Rayfield 2012), and the different morphologies of the coracoscapular joint may also reflect disparate flight techniques. In this regard, it is notable that a flat facies articularis scapularis is found in some species-rich clades of arboreal birds, such as Eucavitaves (the clade including Trogoniformes, Coraciiformes, and Piciformes), Cuculiformes, Columbiformes, Psittaciformes, and Passeriformes. At least in passerines, the furcula acts as a spring, but this function is not assumed by the furcula of, e.g., many Piciformes, in which both clavicles are not fused at their sternal extremities (Jenkins et al. 1988).

A weakly developed furcula may be related to agile locomotion in dense vegetation, which conforms to the presence of a flat facies in the Enantiornithes (see "Introduction"), the predominant clade of arboreal Mesozoic birds. However, the assumption that a flat facies improves wing flapping capabilities or enables hovering flight does not seem to apply, and in some taxa, the opposite seems to be true. In the Procellariiformes, for example, a cotyla scapularis occurs in the broad-winged Oceanitidae, which employ flapping flight to a greater degree than the Diomedeidae, Hydrobatidae, and Procellariidae, with the latter three taxa being adapted to dynamic soaring (flapping flight was also assumed for the extinct Diomedeoididae, which like the Oceanitinae have a cup-like cotyla scapularis; Mayr 2017a). Hummingbirds also employ powerful wing flapping and have a cup-like cotyla 


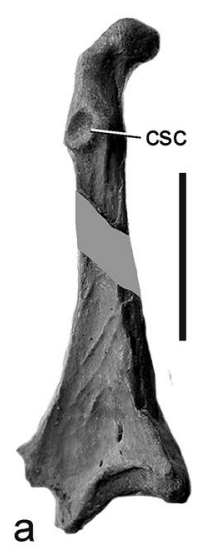

b
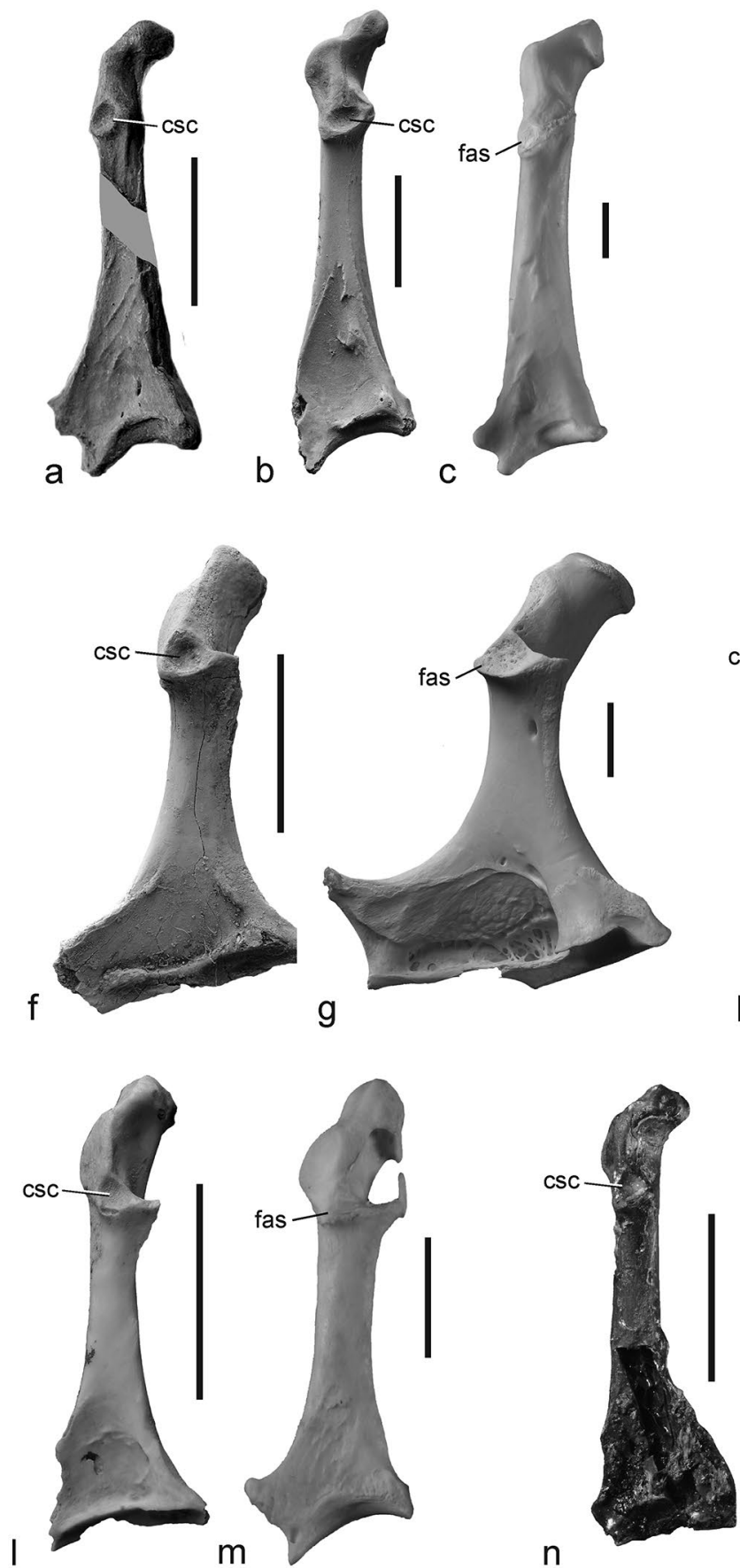

n
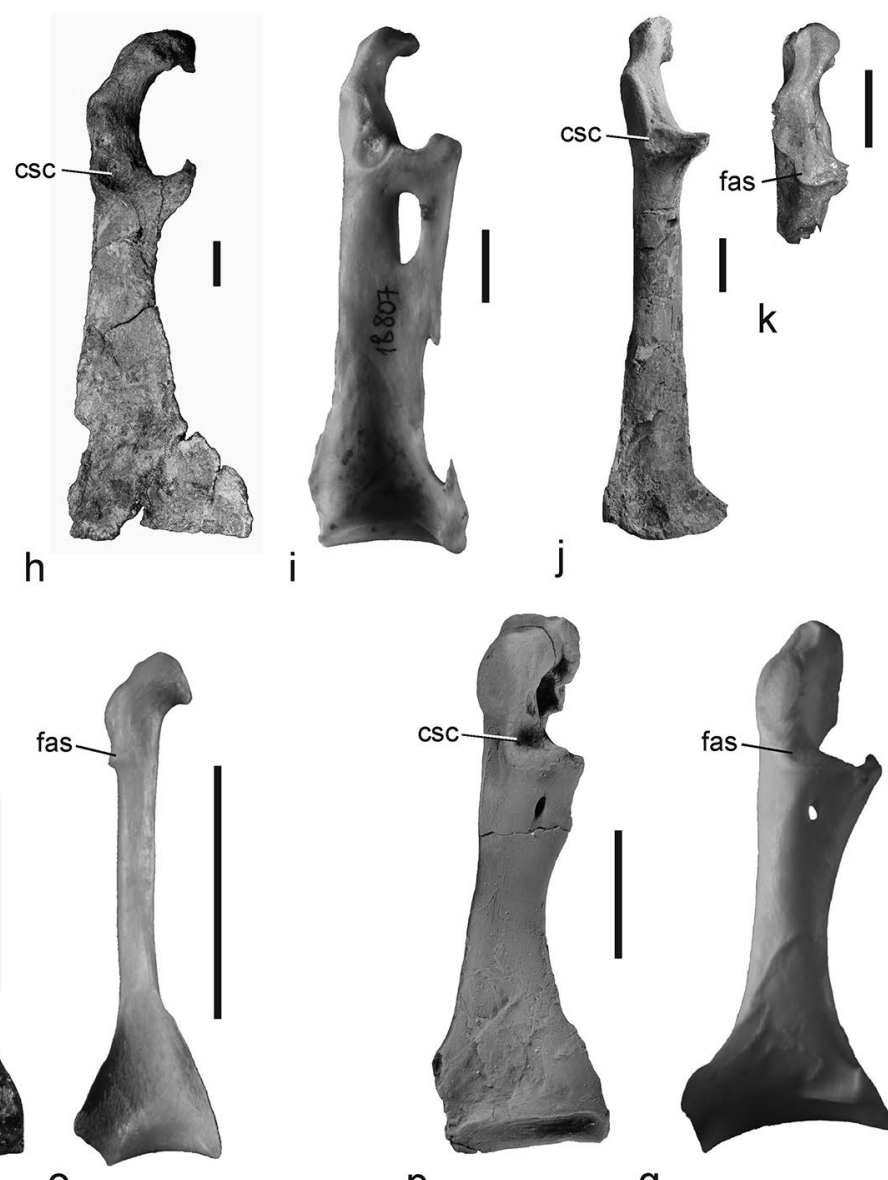

0

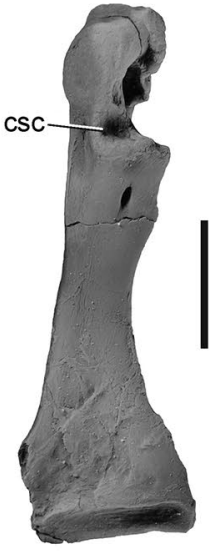

$\mathrm{p}$

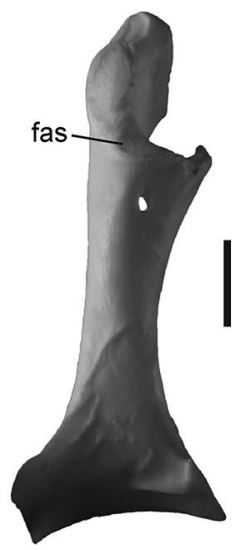

q
Fig. 2 Left coracoids in dorsal view to illustrate the transition from a cotyla scapularis (csc) to a facies articularis scapularis (fas) in the stem lineages of several neornithine taxa. a-c Galliformes, with a the early Eocene stem group galliform Gallinuloides wyomingensis (WDC CGR-012; the surrounding matrix was digitally removed, the gray area indicates a digitally removed overlying bone), b the early Oligocene paraortygid cf. Pirortyx major (IRSNB Av 117), and $\mathbf{c}$ the extant Pavo cristatus (Phasianidae). d, e Pelagornithidae, with d the Paleocene Protodontopteryx ruthae (CM 2018.124.8) and e the Miocene Pelagornis chilensis (MNHN SGO.PV 1061; right coracoid, reversed). f, g Procellariiformes, with $\mathbf{f}$ the early Oligocene diomedeoidid Rupelornis definitus (IRSNB Av 112a) and g the extant Thalassarche melanophris (Diomedeidae). h, i Sphenisciformes, with h the Paleocene stem group sphenisciform Sequiwaimanu rosieae (CM 2016.6.1) and $\mathbf{i}$ the extant Eudyptes chrysocome (Spheniscidae). j, k Plotopteridae, with $\mathbf{j}$ a late Eocene/early Oligocene species identified as ?Tonsala sp. (SMF Av 614; right side, mirrored, surrounding matrix digitally removed) and $\mathbf{k}$ the late Oligocene Plotopterum joaquinensis (LACM 8927). l, m Psittaciformes, with $\mathbf{l}$ the late Eocene stem group psittaciform Quercypsitta ivani (UCBL FSL 367080) and $\mathbf{m}$ the extant Psittacus erithacus (Psittacidae). n, o Coliiformes, with $\mathbf{n}$ the middle Eocene sandcoleid Eoglaucidium pallas (GMH XXXV-576) and o the extant Colius striatus (Coliidae). $\mathbf{p}, \mathbf{q}$ Strigiformes, with $\mathbf{p}$ the early Eocene Primoptynx poliotauros (UMMP 96195) and $\mathbf{q}$ the extant Bubo scandiacus (Strigidae). Scale bars equal $10 \mathrm{~mm}$ 

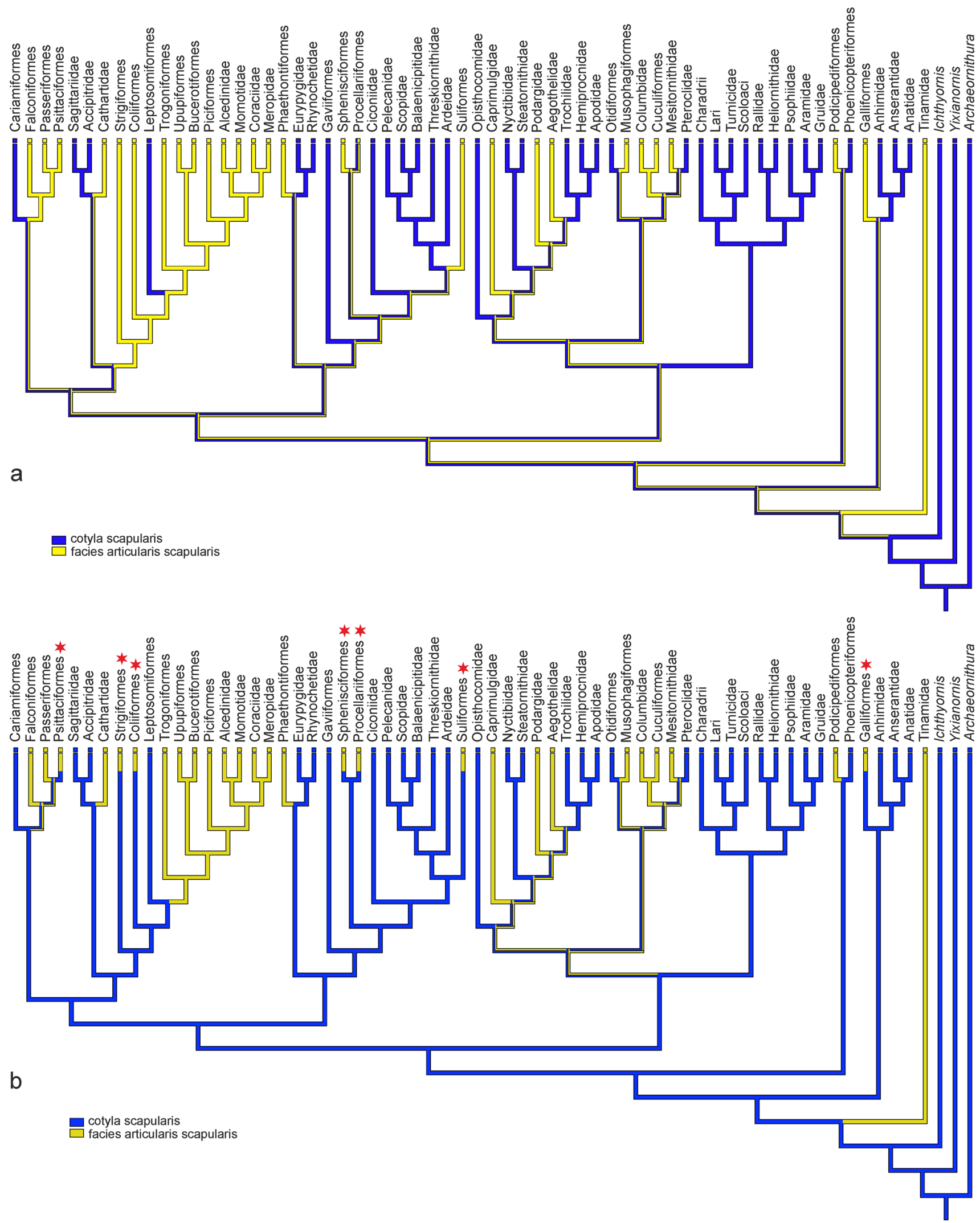
4Fig. 3 a Ancestral state reconstruction for the distribution of the different morphologies of the coracoscapular joint in extant birds, based on the phylogeny of Kuhl et al. (2021) and the data in Table 1; taxa with a cotyla scapularis are shown in blue, those with a facies articularis scapularis in yellow. b A second analysis, in which extant taxa with a flat facies articularis scapularis that have fossil stem lineage representatives with a cotyla scapularis were scored as having a cotyla; for these taxa, which are denoted with a red asterisk, the short yellow terminal branches were added to the figure after the analysis. Ichthyornis, Yixianornis, and Archaeornithura are Cretaceous stem group representatives of the Ornithuromorpha

scapularis, even though they "have kinematically 'rigid' wings compared with other avian species" (Tobalske et al. 2007: 2368).

As detailed in the introduction, a cup-like cotyla scapularis evolved in the stem lineage of the Ornithuromorpha and allows multidirectional movements of the coracoid relative to the scapula. Because early ornithuromoph birds had a very rigid furcula, this cup-shaped articulation was the major mobile joint of the pectoral girdle and is likely to have absorbed mechanical strain on the pectoral girdle elements resulting from contractions of a powerful supracoracoideus muscle. Here it is hypothesized that in taxa that have a bendable furcula with weakly developed shafts, transverse mobility of the coracoscapular joint is no longer functionally necessary and was abandoned with the formation of a flat facies articularis scapularis that constrained the relative movements between the coracoid and scapula to the paramedian plane.

In addition, a cup-like cotyla scapularis was reduced in some soaring birds, in which wing flapping plays a subordinate role. As detailed above, this is exemplified by the coracoscapular joint of procellariiform birds, in which species that are adapted to dynamic soaring have a flat facies articularis scapularis. Similar considerations may pertain to the Pelagornithidae, in which the Paleocene Protodontopteryx, which is considered to have retained flapping flight capabilities (Mayr et al. 2021b), had a larger and more deeply concave cotyla scapularis than the giant Neogene species, which were highly specialized soaring birds (Fig. 2d, e).

A correlation between the robustness of the furcula and the morphology of the coracoscapular joint is particularly evident in the Galliformes, where Paleogene stem group representatives have a much more robust furcula than the extant taxa (Fig. 4g, h). Stegmann (1964) showed that reduction of the furcula in galliform birds is related to the development of a large crop. The furcula serves as an insertion site for the cranial portion of musculus pectoralis, and the curvature of the bone results in a cranial position of a portion of this muscle relative to the humerus, which enables the bird to draw the wings forward (see also Bock 2013). In extant Galliformes and other birds with a large crop (e.g., Psittacidae and Columbidae), the furcula is only weakly developed and lacks a cranial curvature. Musculus pectoralis therefore cannot assume the above function, which is adopted by an unusually well-developed musculus coracobrachialis cranialis (Stegmann 1964). This latter muscle originates on the processus acrocoracoideus of the coracoid, and a flat facies articularis scapularis may counteract transverse movements of the coracoid during the contraction of musculus coracobrachialis cranialis and thereby increase the efficiency of this muscle. Similar considerations may apply to psittaciform, and columbiform birds, which likewise have a large crop, a reduced furcula, and a flat facies articularis scapularis.

For some taxa, correlations between the morphology of the coracoscapular joint and the development of the furcula shafts or wing movements are not obvious, and more research is needed for a full understanding of the functional significance of the variation found in neornithine birds. The Cathartidae, for example, have a flat facies articularis scapularis and a robust furcula with a wide sternal extremity. These birds are adapted to thermal soaring, so that wing flapping plays a role mainly during take-off and landing. This is, however, also true for various taxa with a deep cotyla scapularis, such as the Ciconiidae, Pelecanidae, and Sagittariidae, and even though the functional considerations proposed in the present study explain some of the observed variation in the morphologies of the neornithine coracoscapular joint, other functional correlations may exist.

The coracoid is a robust bone, which has a comparatively high fossilization potential. As demonstrated above, the different morphologies of the scapular articulation facet are potential indicators of profound changes in the architecture of the pectoral girdle and mark important ecomorphological changes in the stem lineages of certain taxa. Improved knowledge of the functional significance of the different morphologies of the coracoscapular joint of neornithine birds therefore has the potential to inform the paleobiology of extinct taxa, and it is to be hoped that the present study serves to inspire future research in this direction. 

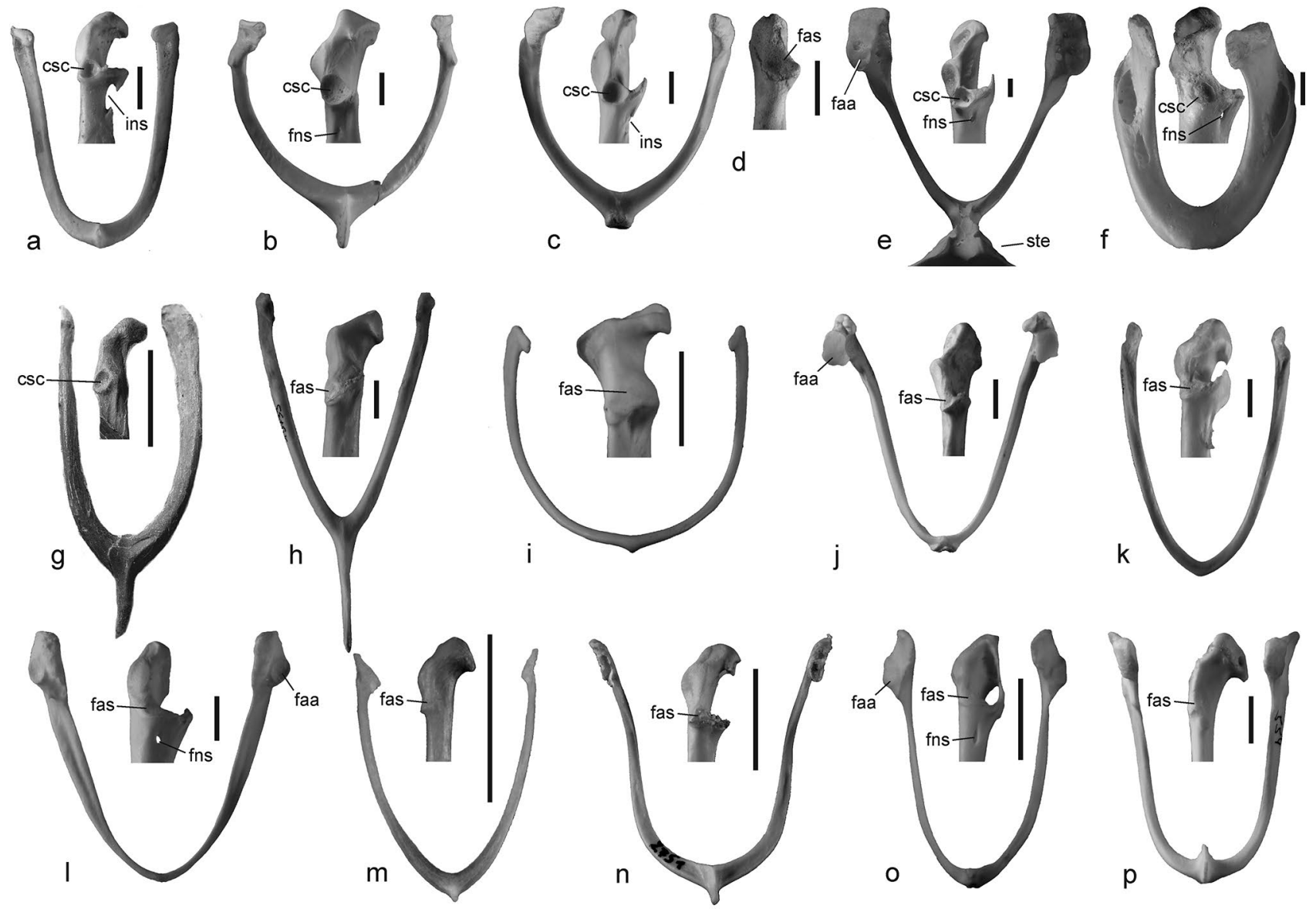

Fig. 4 Different morphologies of the coracoid (left side, dorsal view) and furcula (caudal view) of selected extant birds. a Eupodotis vigorsii (Otidiformes, Otididae). b Sagittarius serpentarius (Accipitriformes, Sagittariidae). c Ciconia ciconia (Ciconiiformes, Ciconiidae). d $C$. ciconia, coracoid of a juvenile individual. e Pelecanus onocrotalus (Pelecaniformes, Pelecanidae). f Anhima cornuta (Anseriformes, Anhimidae). g The early Eocene stem group galliform Gallinuloides wyomingensis (Galliformes, Gallinuloididae. WDC CGR-012). h Pavo cristatus (Galliformes, Phasianidae). i Rhynchotus rufescens

Acknowledgements Sven Tränkner is thanked for taking the photographs. Zhou Zhonghe provided a photo of the Yixianornis coracoid. Comments from two anonymous reviewers improved the manuscript.

Funding Open Access funding enabled and organized by Projekt DEAL.

Open Access This article is licensed under a Creative Commons Attribution 4.0 International License, which permits use, sharing, adaptation, distribution and reproduction in any medium or format, as long as you give appropriate credit to the original author(s) and the source, provide a link to the Creative Commons licence, and indicate if changes were made. The images or other third party material in this article are included in the article's Creative Commons licence, unless indicated otherwise in a credit line to the material. If material is not included in the article's Creative Commons licence and your intended use is not permitted by statutory regulation or exceeds the permitted use, you will
(Tinamiformes, Tinamidae). j Phalacrocorax carbo (Suliformes, Phalacrocoracidae). k Goura victoria (Columbiformes, Columbidae). I Bubo scandiacus (Strigiformes, Strigidae). m Colius striatus (Coliiformes, Coliidae). n Pharomachus pavoninus (Trogoniformes, Trogonidae). o Micrastur ruficollis (Falconiformes, Falconidae). p Corvus corax (Passeriformes, Corvidae). Abbreviations: csc cotyla scapularis, faa facies articularis acrocoracoidea, fas facies articularis scapularis, fns foramen nervi supracoracoidei, ins incisura nervi supracoracoidei, ste sternum. The scale bars equal $10 \mathrm{~mm}$

need to obtain permission directly from the copyright holder. To view a copy of this licence, visit http://creativecommons.org/licenses/by/4.0/.

\section{References}

Baumel JJ, Raikow RJ (1993) Arthrologia. In: Baumel JJ, King AS, Breazile JE, Evans HE, Vanden Berge JC (eds) Handbook of avian anatomy: nomina anatomica avium, vol 23. Nuttall Ornithol Club, pp 133-187

Bell A, Chiappe LM (2020) Anatomy of Parahesperornis: evolutionary mosaicism in the Cretaceous Hesperornithiformes (Aves). Life 10(5):62

Blokland JC, Reid CM, Worthy TH, Tennyson AJ, Clarke JA, Scofield RP (2019) Chatham Island Paleocene fossils provide insight into the palaeobiology, evolution, and diversity of early penguins (Aves, Sphenisciformes). Palaeontol Electron 22:1-92 
Bock WJ (2013) The furcula and the evolution of avian flight. Paleontol J 47:1236-1244

Chiappe LM, Walker CA (2002) Skeletal morphology and systematics of the Cretaceous Euenantiornithes (Ornithothoraces: Enantiornithes). In: Chiappe LM, Witmer LM (eds) Mesozoic birds: above the heads of dinosaurs. University of California Press, Berkeley, pp 240-267

Clarke JA (2004) Morphology, phylogenetic taxonomy, and systematics of Ichthyornis and Apatornis (Avialae: Ornithurae). Bull Am Mus Nat Hist 286:1-179

Clarke JA, Zhou Z, Zhang F (2006) Insight into the evolution of avian flight from a new clade of Early Cretaceous ornithurines from China and the morphology of Yixianornis grabaui. J Anat 208:287-308

Close RA, Rayfield EJ (2012) Functional morphometric analysis of the furcula in Mesozoic birds. PLoS ONE 7(5):e36664

De Pietri VL, Berger JP, Pirkenseer C, Scherler L, Mayr G (2009) New skeleton from the early Oligocene of Germany indicates a stem-group position of diomedeoidid birds. Acta Palaeontol Pol 55:23-34

Fürbringer M (1888) Untersuchungen zur morphologie und systematik der vögel, zugleich ein beitrag zur anatomie der stütz- und bewegungsorgane, vol 2. Van Holkema, Amsterdam

George JC, Berger AJ (1966) Avian myology. Academic Press, New York

Hospitaleche CA (2016) Paleobiological remarks on a new partial skeleton of the Eocene Antarctic penguin Palaeeudyptes klekowskii. Ameghiniana 53:269-281

Hospitaleche CA, Gelfo JN (2015) New Antarctic findings of Upper Cretaceous and lower Eocene loons (Aves: Gaviiformes). Ann Paléontol 101:315-324

Hospitaleche CA, Gelfo JN (2017) Procellariiform remains and a new species from the latest Eocene of Antarctica. Hist Biol 29:755-769

Houde P, Olson SL (1992) A radiation of coly-like birds from the early Eocene of North America (Aves: Sandcoleiformes new order). In: Campbell KE (ed) Papers in avian paleontology honoring Pierce Brodkorb, science series, vol 36. Natural History Museum, Los Angeles, pp 137-160

Hui CA (2002) Avian furcula morphology may indicate relationships of flight requirements among birds. J Morphol 251:284-293

Jadwiszczak P (2006) Eocene penguins of Seymour Island, Antarctica: taxonomy. Pol Polar Res 27:3-62

Jasinoski SC, Russell AP, Currie PJ (2006) An integrative phylogenetic and extrapolatory approach to the reconstruction of dromaeosaur (Theropoda: Eumaniraptora) shoulder musculature. Zool J Linn Soc 146:301-344

Jenkins FA, Dial KP, Goslow GE (1988) A cineradiographic analysis of bird flight: the wishbone in starlings is a spring. Science 241:1495-1498

Ksepka DT, Fordyce RE, Ando T, Jones CM (2012) New fossil penguins (Aves, Sphenisciformes) from the Oligocene of New Zealand reveal the skeletal plan of stem penguins. J Vertebr Paleontol $32: 235-254$

Kuhl H, Frankl-Vilches C, Bakker A, Mayr G, Nikolaus G, Boerno ST, Klages S, Timmermann B, Gahr M (2021) An unbiased molecular approach using 3'UTRs resolves the avian family-level tree of life. Mol Biol Evol. https://doi.org/10.1093/molbev/msaa191 (in press)

Longrich N (2009) An ornithurine-dominated avifauna from the Belly River Group (Campanian, Upper Cretaceous) of Alberta, Canada. Cretac Res 30:161-177

Maddison WP, Maddison DR (2009) Mesquite: a modular system for evolutionary analysis; version 2.71. http://mesquiteproject.org. Accessed Nov 2009
Mayr G (2006) New specimens of the early Eocene stem group galliform Paraortygoides (Gallinuloididae), with comments on the evolution of a crop in the stem lineage of Galliformes. J Ornithol 147:31-37

Mayr G (2017a) Avian evolution: the fossil record of birds and its paleobiological significance. Wiley-Blackwell, Chichester

Mayr G (2017b) Pectoral girdle morphology of Mesozoic birds and the evolution of the avian supracoracoideus muscle. J Ornithol 158:859-867

Mayr G, Goedert JL (2017) Oligocene and Miocene albatross fossils from Washington State (USA) and the evolutionary history of North Pacific Diomedeidae. Auk 134:659-671

Mayr G, Smith T (2012) Phylogenetic affinities and taxonomy of the Oligocene Diomedeoididae, and the basal divergences amongst extant procellariiform birds. Zool J Linn Soc 166:854-875

Mayr G, Smith T (2013) Galliformes, Upupiformes, Trogoniformes, and other avian remains (?Phaethontiformes and ?Threskiornithidae) from the Rupelian stratotype in Belgium, with comments on the identity of "Anas" benedeni Sharpe, 1899. In: Paleornithological research 2013-proceedings of the 8th international meeting of the Society of Avian Paleontology and Evolution, Göhlich UB, Kroh A (Eds). Natural History Museum Vienna, Vienna, pp 23-35

Mayr G, Weidig I (2004) The Early Eocene bird Gallinuloides wyomingensis - a stem group representative of Galliformes. Acta Palaeontol Pol 49:211-217

Mayr G, De Pietri VL, Love L, Mannering AA, Scofield RP (2018) A well-preserved new mid-Paleocene penguin (Aves, Sphenisciformes) from the Waipara Greensand in New Zealand. J Vertebr Paleontol 37:e1398169

Mayr G, Gingerich PD, Smith T (2020) Skeleton of a new owl from the early Eocene of North America (Aves, Strigiformes) with an accipitrid-like foot morphology. J Vertebr Paleontol 40:e1769116

Mayr G, Goedert JL, De Pietri VL, Scofield RP (2021a) Comparative osteology of the penguin-like mid-Cenozoic Plotopteridae and the earliest true fossil penguins, with comments on the origins of wing-propelled diving. J Zool Syst Evol Res 59:264-276

Mayr G, De Pietri VL, Love L, Mannering AA, Scofield RP (2021b) Oldest, smallest, and phylogenetically most basal pelagornithid, from the early Paleocene of New Zealand, sheds light on the evolutionary history of the largest flying birds. Pap Palaeontol. https:// doi.org/10.1002/spp2.1284

Mourer-Chauviré C (1992a) The Galliformes (Aves) from the Phosphorites du Quercy (France): systematics and biostratigraphy. In: Campbell KE (ed) Papers in avian paleontology honoring Pierce Brodkorb, science series, vol 36. Natural History Museum, Los Angeles, pp 67-95

Mourer-Chauviré C (1992b) Une nouvelle famille de perroquets (Aves, Psittaciformes) dans l'Éocène supérieur des Phosphorites du Quercy, France. Geobios 25:169-177

Mourer-Chauviré C (2000) A new species of Ameripodius (Aves: Galliformes: Quercymegapodiidae) from the lower Miocene of France. Palaeontol 43:481-493

Mourer-Chauviré C, Berthet D, Hugueney M (2004) The late Oligocene birds of the Créchy quarry (Allier, France), with a description of two new genera (Aves: Pelecaniformes: Phalacrocoracidae, and Anseriformes: Anseranatidae). Senckenberg Leth 84:303-315

Mourer-Chauviré C, Pickford M, Senut B (2017) New data on stem group Galliformes, Charadriiformes, and Psittaciformes from the middle Eocene of Namibia. Contrib MACN 7:99-131

Olson SL (1977) A Lower Eocene frigatebird from the Green River Formation of Wyoming (Pelecaniformes: Fregatidae). Smithson Contrib Paleobiol 35:1-33

Senter P (2006) Scapular orientation in theropods and basal birds, and the origin of flapping flight. Acta Palaeontol Pol 51:305-313 
Stegmann B (1964) Die funktionelle Bedeutung des Schlüsselbeines bei den Vögeln. J Ornithol 105:450-463

Sy M (1936) Funktionell-anatomische untersuchungen am vogelflügel. J Ornithol 84:199-296

Temrin H, Tullberg BS (1995) A phylogenetic analysis of the evolution of avian mating systems in relation to altricial and precocial young. Behav Ecol 6:296-307

Tobalske BW, Warrick, DR, Clark CJ, Powers DR, Hedrick TL, Hyder, GA, Biewener AA (2007) Three-dimensional kinematics of hummingbird flight. J Exp Biol 210:2368-2382

Wang M, Zheng X, O'Connor JK, Lloyd GT, Wang X, Wang Y, Zhang X, Zhou Z (2015) The oldest record of Ornithuromorpha from the Early Cretaceous of China. Nat Commun 6:6987
Wang Y-M, O’Connor JK, Li D-Q, You H-L (2016) New information on postcranial skeleton of the Early Cretaceous Gansus yumenensis (Aves: Ornithuromorpha). Hist Biol 28:666-679

Wang M, Stidham TA, Zhou Z (2018) A new clade of basal Early Cretaceous pygostylian birds and developmental plasticity of the avian shoulder girdle. Proc Natl Acad Sci 115:10708-10713

Yuri T, Kimball RT, Harshman J, Bowie RCK, Braun MJ, Chojnowski JL, Han KL, Hackett SJ, Huddleston CJ, Moore WS, Reddy S, Sheldon FH, Steadman DW, Witt CC, Braun EL (2013) Parsimony and model-based analyses of indels in avian nuclear genes reveal congruent and incongruent phylogenetic signals. Biology $2: 419-444$

Publisher's Note Springer Nature remains neutral with regard to jurisdictional claims in published maps and institutional affiliations. 